\title{
OPEN Cell viability and electrical response of breast cancer cell treated in aqueous graphene oxide solution deposition on interdigitated electrode
}

\author{
Muhammad M. Ramli, ${ }^{1,2}$, A. S. Rosman ${ }^{1}$, N. S. Mazlan' ${ }^{1}$, M. F. Ahmad ${ }^{1,2}$, D. S. C. Halin ${ }^{2}$,
} R. Mohamed ${ }^{3}$, Nurul H. Osman ${ }^{4 凶}$ \& Ali H. Reshak ${ }^{2,5,6}$

Breast cancer is one of the most reported cancers that can lead to death. Despite the advances in diagnosis and treatment procedures, the possibility of cancer recurrences is still high in many cases. With that in consideration, researchers from all over the world are showing interest in the unique features of Graphene oxide (GO), such as its excellent and versatile physicochemical properties, to explore further its potential and benefits towards breast cancer cell treatment. In this study, the cell viability and electrical response of $\mathrm{GO}$, in terms of resistivity and impedance towards the breast cancer cells (MCF7) and normal breast cells (MCF10a), were investigated by varying the $\mathrm{pH}$ and concentration of GO. Firstly, the numbers of MCF7 and MCF10a were measured after being treated with GO for 24 and $48 \mathrm{~h}$. Next, the electrical responses of these cells were evaluated by using interdigitated gold electrodes (IDEs) that are connected to an LCR meter. Based on the results obtained, as the $\mathrm{pH}$ of GO increased from $\mathrm{pH} 5$ to $\mathrm{pH} 7$, the number of viable MCF7 cells decreased while the number of viable MCF10a slightly increased after the incubation period of $48 \mathrm{~h}$. Similarly, the MCF7 also experienced higher cytotoxicity effects when treated with $\mathrm{GO}$ concentrations of more than $25 \mu \mathrm{g} /$ $\mathrm{mL}$. The findings from the electrical characterization of the cells observed that the number of viable cells has corresponded to the impedance of the cells. The electrical impedance of MCF7 decreased as the number of highly insulating viable cell membranes decreased. But in contrast, the electrical impedance of MCF10a increased as the number of highly insulating viable cell membranes increased. Hence, it can be deduced that the $\mathrm{GO}$ with higher $\mathrm{pH}$ and concentration influence the MCF7 cancer cell line and MCF10a normal breast cell.

The research on Graphene Oxide (GO) involved in medical applications has increased constantly throughout the years. The medical applications of GO include drug delivery ${ }^{1,2}$, tissue engineering ${ }^{3}$, diagnostics and cancer treatment ${ }^{4,5}$. The interactions between graphene-based nanomaterials with biological systems were previously discovered and explored ${ }^{1,5,6}$. However, there is still a lack of scientific support to determine the cytotoxicity effects caused by nanomaterials towards the normal and cancer cells. Hence, the crucial mechanisms of nanotoxicity due to the production of reactive oxygen species (ROS) were studied ${ }^{3,7}$. When the ROS is over generated, it also creates oxidative stress that leads to the failure of the cells to maintain the normal physiological redox-regulated functions. This consequently resulted in DNA damage, imbalance of cell signals and changes in cells cytotoxicity,

${ }^{1}$ Faculty of Electronic Engineering Technology, Universiti Malaysia Perlis (UniMAP), Pauh Putra Campus, 02600 Kangar, Perlis, Malaysia. ${ }^{2}$ Geopolymer \& Green Technology, Centre of Excellence (CEGeoGTech), Universiti Malaysia Perlis (UniMAP), Pauh Putra Campus, 02600 Kangar, Perlis, Malaysia. ${ }^{3}$ Regenerative Medicine Cluster, Advance Medical and Dental Institute, Universiti Sains Malaysia, Bertam, 13200 Kepala Batas, Pulau Pinang, Malaysia. ${ }^{4}$ Applied Electromagnetic Laboratory 1, Department of Physics, Faculty of Science, Universiti Putra Malaysia, 43400 Serdang, Selangor, Malaysia. ${ }^{5}$ Physics Department, College of Science, University of Basrah, 61004 Basrah, Iraq. ${ }^{6}$ Department of Instrumentation and Control Engineering, Faculty of Mechanical Engineering, Czech Technical Universiti in Prague, Technicka 4, Prague 6166 07, Czech Republic. ${ }^{\square}$ email: nurulhuda@ upm.edu.my 
apoptosis and cancer initiation. By comparing the normal and cancer cells, the ROS production and oxidative stresses are much higher in the cancer cells, making them more likely to undergo cell mutations, uncontrolled initiation of cellular proliferation, genetic instability and cell death. Therefore, the potential of graphene-based biomaterials to inhibit cancer that can limit ROS production, as these have the potential to affect the cell viability of cancerous cells ${ }^{3}$. According to Ref. ${ }^{8}$, even though graphene or graphene-based nanomaterials exhibited no effect on the mammalian cells at low concentrations, but high graphene concentrations can affect the cell membrane integrity and cause cell death. These findings were similar and were also supported by Refs. ${ }^{4,5}$. These studies suggested that the interactions between the high concentrations of graphene or graphene-based materials with the cells can degrade the cell membrane integrity, including the early-stage breast cancer cells (MCF7), pancreatic cancer cells (Panc-1), and invasive breast cancer cells (MDA-MB-231).

Most commonly used biosensors are affinity-based. The affinity-based biosensor is referred to as an immobilized capture probe that binds to a particular target, therefore causing physiochemical changes that can be detected by a transducer ${ }^{9}$. So that the cancer diagnosis can be made in a short time. The interdigitated electrode (IDEs) is one of the promising alternatives to assimilate the biosensors into a portable lab-on-chip device due to its ability to detect electrical changes in terms of impedance, resistance or capacitance ${ }^{10}$. As stated by Ref. ${ }^{11}$, IDEs are usually used for various applications, especially as biological and chemical sensors, due to the low cost of production, ease of fabrication and high sensitivity.

The research by Ref. ${ }^{12}$ illustrated the principles of electrochemical impedance spectroscopy (EIS) measurement during the presence and absence of cells on the Bode impedance spectra. When there are no cells attached, the impedance will only be obtained from the resistance of the solution, $\mathrm{R}_{\mathrm{sol}}$ and the double-layer capacitance of the electrode, $\mathrm{C}_{\mathrm{d} \text {. }}$. However, when cells are deposited on the electrode surface, the newly formed equivalent circuit will include the impedance inclusive of the resistance of the dropped cells, $R_{\text {cell }}$ and its capacitance, $\mathrm{C}_{\text {cell }}$ attached in parallel. The presence of cells also influences the changes of interface impedance, where the impedance will increase due to the insulating cells membranes. This eventually triggers the ionic environment changes around the electrode or solution interfaces, thus leading to the changes in $\mathrm{R}_{\mathrm{sol}}$ and $\mathrm{C}_{\mathrm{dl}}$ values. As stated in Eqs. (1) and $(2)$, the capacitance $\left(C_{\text {cell }}\right)$ that contributes to the impedance $\left(Z^{\prime \prime}\right)$ is depending on the frequency $(f)$, while the resistance $\left(R_{\text {cell }}\right)$ that contributes to the impedance $\left(Z^{\prime}\right)$ is independent of the frequency. Hence, when the cells are attached at the electrode surface, the new magnitude impedance, $\mathrm{Z}_{\text {cell }}$ that consists of $\mathrm{R}_{\text {cell }}$ and $\mathrm{C}_{\text {cell }}$ is generated, as shown in Eq. (3).

$$
\begin{gathered}
Z^{\prime \prime}=\frac{1}{2 \pi f C_{c e l l}}, \\
Z^{\prime}=R_{c e l l}, \\
Z_{c e l l}=\sqrt{R_{c e l l}^{2}+\frac{1}{\left(2 \pi f C_{c e l l}\right)^{2}}}, \\
\varnothing=\tan ^{-1}\left(\frac{-1}{2 \pi f R_{c e l l} C_{c e l l}}\right) .
\end{gathered}
$$

The new potential of GO in affecting cancerous cells is explored, as it has good surface functionality due to the oxidation process produced by using Hummer's method. Hence, GO was chosen to observe the treatment effects on MCF7 breast cancer cells and MCF10a normal breast based on the cell viability and after the incubation period of $24 \mathrm{~h}$ and $48 \mathrm{~h}$. Even though the studies elucidating the effects of GO on normal cells are very limited in comparing studies on GO impact on cancer cells, the precise mechanism that cause difference effect GO on normal and cancer cells is still unknown ${ }^{13}$. Therefore, in contrast to the previous research, the electrical responses and effects of MCF7 and MCF10a without using any redox solutions or biomarkers were studied to observe the direct interactions between the cells and GO. This is very important to fully understand the electrical responses between the cells, as it may be useful for developing an early breast cancer detection device.

\section{Experimental details}

Pre-oxidized graphite. The first step of the study was to prepare the pre-oxidized graphite by following the protocol reported by Ref. ${ }^{14}$. Firstly, a mixture was prepared by dissolving $3 \mathrm{~g}$ of graphite powder (NE Scientific, Malaysia), $2.5 \mathrm{~g}$ of potassium persulfate $\left(\mathrm{P}_{2} \mathrm{~S}_{2} \mathrm{O}_{8}\right)$ (Sigma-Aldrich, USA) and $2.5 \mathrm{~g}$ of phosphorus pentoxide $\left(\mathrm{P}_{2} \mathrm{O}_{5}\right)$ (Sigma-Aldrich, USA) in $12 \mathrm{~mL}$ of sulfuric acid $\left(\mathrm{H}_{2} \mathrm{SO}_{4}\right)$ (Sigma-Aldrich, USA). Then, the solution mixture was kept in an oil bath for four and a half hours under the temperature of $80^{\circ} \mathrm{C}$. Next, the mixture was cooled to the ambient temperature before it was diluted further with $500 \mathrm{~mL}$ of deionized (DI) water and left overnight. Finally, the mixture was filtered by using a $0.22 \mu \mathrm{m}$ PTFE membrane and was washed with DI water to achieve neutral conditions through removing the residual acid.

Modified Hummer's method. This section described Hummer's method to produce the aqueous GO with some modification. First, the pre-oxidized graphite was added into $120 \mathrm{~mL}$ of concentrated sulfuric acid pre-chilled to $0{ }^{\circ} \mathrm{C}$ and was kept incubated inside an ice bath. Then, $15 \mathrm{~g}$ of potassium permanganate $\left(\mathrm{KMnO}_{4}\right)$ (Sigma-Aldrich, USA) was added gradually into the mixture to prevent extravagant heat. The mixture was stirred at $800 \mathrm{rpm}$ and must be kept under $20^{\circ} \mathrm{C}$. Then, the mixture was stirred for $2 \mathrm{~h}$ under $35^{\circ} \mathrm{C}$. After that, 
the mixture was added with $250 \mathrm{~mL}$ of DI water, before being placed into the ice bath for another $2 \mathrm{~h}$. Next, $700 \mathrm{~mL}$ of DI water was added, followed by $20 \mathrm{~mL}$ of $30 \%$ concentrated hydrogen peroxide $\left(\mathrm{H}_{2} \mathrm{O}_{2}\right)$ (SigmaAldrich, USA). This reaction generated an aggressive spark, while the temperature rose to $70{ }^{\circ} \mathrm{C}$. Meanwhile, the mixture changed to a yellowish color and indicated the production of well-oxidized graphite oxide. To remove the metal ions, the mixture was filtered and washed with $1: 10 \mathrm{HCl}$ solution, followed by $1 \mathrm{~L}$ of DI water to discard the residual acid. The resulting graphite oxide powder was dried at room temperature and weighed. Appropriate amount of GO powder was then dissolved with DI water to fix the concentration to $30 \mathrm{mg} / \mathrm{mL}$.

The production of different $\mathrm{pH}$ of GO. The aqueous GO solution was prepared into $\mathrm{pH}$, by firstly using the titration method with the ratio of $\mathrm{HCl}$ : GO solution = 1:10. Next, the analyte solution was centrifuged at $6000 \mathrm{rpm}$ for $30 \mathrm{~min}$ to obtain the concentrated graphite oxide. The separated supernatant liquid was removed and fresh DI water was added into the GO (the solid product) before the $\mathrm{pH}$ of the solution was measured (HI $98130 \mathrm{pH}$ tester, HANNA Instrument, USA). The process of centrifugation, removing the supernatant liquid and adding fresh DI water was repeated for 16 times until pH 5 was achieved. For pH 6 and 7, those processes were repeated for 20 times and 24 times, respectively.

The production of different concentration of GO. For this experiment, $5 \mathrm{mg} / \mathrm{mL}$ of GO with a $\mathrm{pH}$ of 5 was used to prepare a stock solution. Then, this GO stock solution was further diluted with DI water to produce 6 different concentrations; $2.5,6.25,12.5,25,50$ and $100 \mu \mathrm{g} / \mathrm{mL}$, respectively.

GO characterization. The GO was characterized by using Raman spectroscopy (HORIBA Scientific, Xplora Plus, USA), X-ray Diffraction spectroscopy (XRD, Malvern Panalytical, Netherlands), Field Emission Scanning Electron Microscope (FESEM, Nova Nanosem 230, FEI, North America), Energy-Dispersive X-ray spectroscopy (EDX, Nova Nanosem 230, FEI, North America) and Thermogravimetric analysis (TGA, TGADSC HT 3, Mettler Toledo, USA) in order to validate and confirm the morphology and graphitic nature of GO.

Cell culture. The breast cancer cell (MCF7) obtained from Advanced Medical and Dental Institute (AMDI, Universiti Sains Malaysia, USM) were cultured in RPMI 1640 medium (Gibco, USA) supplemented with 5\% fetal bovine serum (FBS) (Gibco, USA) and $1 \%$ penicillin-streptomycin (Gibco, USA) were incubated in a $90 \%$ humidified atmosphere with $5 \% \mathrm{CO}_{2}$ under $37^{\circ} \mathrm{C}$. The normal breast cell (MCF10a), also obtained from AMDI, (USM) were cultured in Dulbecco's Modified Eagle Medium (DMEM) (Thermo Fisher Scientific, USA) supplemented with $10 \mu \mathrm{g} / \mathrm{mL}$ insulin (Thermo Fisher Scientific, USA), $20 \mathrm{ng} / \mathrm{mL}$ human epidermal growth factor (HEGF) (Thermo Fisher Scientific, USA), $0.5 \mu \mathrm{g} / \mathrm{mL}$ hydrocortisone (Thermo Fisher Scientific, USA), $5 \%$ horse serum (Thermo Fisher Scientific, USA) and 5\% penicillin-streptomycin (Gibco, USA). The cells were also incubated in a $90 \%$ humidified atmosphere with $5 \% \mathrm{CO}_{2}$ under $37^{\circ} \mathrm{C}$.

Cell viability. MCF7 $\left(1 \times 10^{4}\right.$ cells $\left./ \mathrm{mL}\right)$ and MCF10a $\left(1 \times 10^{4}\right.$ cells $\left./ \mathrm{mL}\right)$ were seeded into 96 -well plates for $24 \mathrm{~h}$. Then, each well was added with either different $\mathrm{pH}(\mathrm{pH}$ of 5, 6 and 7) and concentrations (concentration of $2.5,6.25,12.5,25,50$ and $100 \mu \mathrm{g} / \mathrm{mL}$ ) of GO, or with only medium. After that, the plates were incubated for an additional 24 and $48 \mathrm{~h}$. After incubation, the medium was discarded, and $10 \mu \mathrm{L}$ of PrestoBlue (Thermo Fisher Scientific, USA) reagent (final volume $100 \mu \mathrm{L}$, freshly diluted in RPMI and DMEM immediately before treatment) was added and incubated for another $1 \mathrm{~h}$. The experiment for every condition of untreated and GO treated cells was conducted in triplicate for each 96-well plates and was repeated three times. The results were measured with the excitation wavelength set at $590 \mathrm{~nm}$ for the fluorescent signal detection mode, by using the FLUOstar Omega microplate reader (BMG LABTECH, Australia). The percentage number of viable cells was calculated by using the Eqs. (5) to (8) as shown below.

$$
\begin{gathered}
\text { Average media }=(\text { summation of three well plates for media only }) \div 3, \\
\text { No. of cells }=(\text { Untreated cell or treated cell for each well })-\text { average media, } \\
\text { Average untreated cells }=(\text { summation of three well plates for untreated cells }) \div 3, \\
\text { No. of viable cells }(\%)=(\text { Average treated cell } \div \text { average untreated cell }) \times 100 \%
\end{gathered}
$$

Electrical characterization. The electrical responses of MCF7 and MCF10a cells on IDE were investigated by using an LCR meter (Agilent E4980 $20 \mathrm{~Hz}-2 \mathrm{MHz}$ Precision LCR (Inductance, Capacitance, Resistance) meter, USA). Briefly, the cell's medium was firstly removed, then MCF7 and MCF10a with and without the GO treatment were trypsinized and the reaction was terminated by adding newly fresh medium. The cells in suspension were then centrifuged, in order to get the cell's pellets. Then, $1.5 \mathrm{~mL}$ of medium was added and the cells were manually counted using hemocytometer. Lastly, $5 \mu \mathrm{L}$ of the MCF7 and MCF10a cells were deposited onto the IDE by using the drop cast method. The $Z_{\text {cell }}$ and resistance changes before and after deposition were then monitored at a frequency between $20 \mathrm{~Hz}$ to $2 \mathrm{MHz}$ using the LCR meter. 


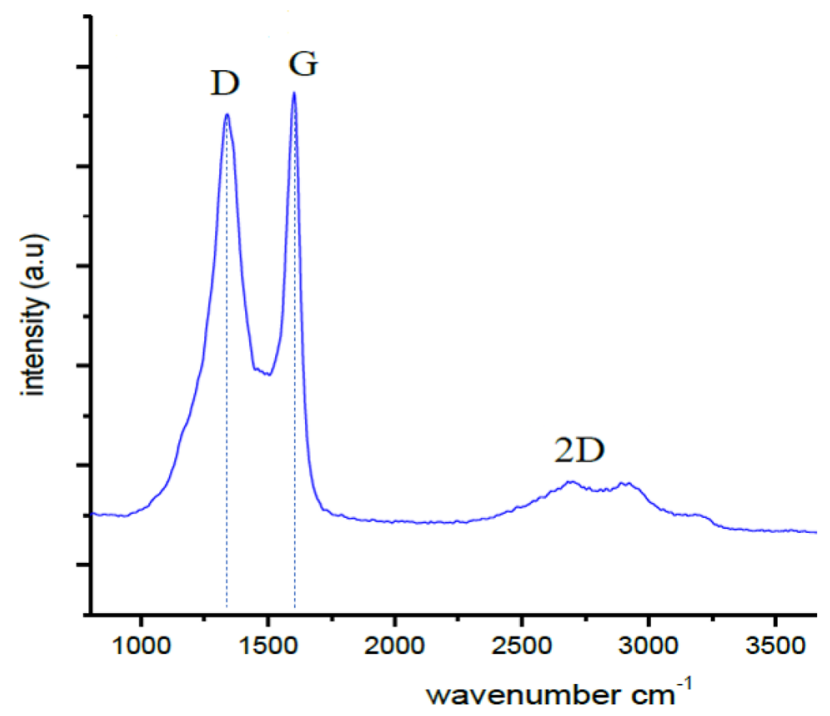

Figure 1. Raman spectrum of GO shows the present of D peak at $1377 \mathrm{~cm}^{-1}$ and $G$ peak at $1580 \mathrm{~cm}^{-1}$ and 2D peak at $2700 \mathrm{~cm}^{-1}$.

\section{Results and discussion}

GO characterization. The obtained GO was first characterized by using the Raman spectroscopy, XRD spectroscopy, FESEM, EDX spectroscopy and Thermogravimetric analysis (TGA) to confirm the graphitic nature, crystal structure, morphology, composition of elements and decarboxylation process respectively. Firstly, Raman spectroscopy was used in order to study the defects and the structure's order of the GO. According to graphitic nature, the $\mathrm{D}$ and $\mathrm{G}$ peaks can be detected in the range of $1200-1500 \mathrm{~cm}^{-1}$ and $1500-1800 \mathrm{~cm}^{-1}$ wavenumber respectively. From the image obtained by using the Raman spectroscopy, the presence of a defect characteristic, D peak at $1377 \mathrm{~cm}^{-1}$ (as shown in Fig. 1) can be seen. The peak may be produced by the disordered bands in $\mathrm{sp}^{2}$ hybridized carbon materials and led to the disruption of the symmetrical hexagonal graphitic lattice as a result of edge defects, internal structural defects and dangling bonds ${ }^{15}$. Meanwhile, the G peak was centered at $1580 \mathrm{~cm}^{-1}$ and was referred to as the first order of the Raman band creating a $\mathrm{D}$ to $\mathrm{G}$ ratio of 0.87 . This may be caused by all the $\mathrm{sp}^{2}$ hybridized carbon materials that were related to the $\mathrm{C}-\mathrm{C}$ vibrational mode ${ }^{16}$. The shift in the G band from $1582 \mathrm{~cm}^{-1}$ to $1599 \mathrm{~cm}^{-1}$ of GO was due to the presence of isolated double bonds on the GO carbon network ${ }^{15}$. Finally, the $2 \mathrm{D}$ peak was also detected at $2700 \mathrm{~cm}^{-1}$.

Next, the X-Ray Diffraction (XRD) was used to identify the phase identification of the crystalline structure in GO. Before conducting the test, the GO solution was first deposited onto the Silicon Dioxide $\left(\mathrm{SiO}_{2}\right)$ substrate by using a drop cast method. The XRD pattern in Fig. 2 was comparable to that obtained by Ref. ${ }^{16}$, confirming the crystalline nature of graphite and GO. In the data, graphite exhibited a sharp peak at $2 \Theta=26.73$ degrees with $\mathrm{d}$-spacing at $3.33 \AA$. After the oxidation of graphite, the sharp reflection peak was shifted to the lower angle at $2 \Theta=11.54$ degrees with $d$-spacing at $7.67 \AA$, due to the formation of oxygen functional groups and the intercalation of water molecules into the carbon layer structure ${ }^{17}$.

For Field Emission Scanning Electron Microscopy observation, the FESEM was operated at $15 \mathrm{kV}$ and at a constant working distance of $4.9 \mathrm{~mm}$ to produce the optimal imaging conditions. This analysis is primarily used to determine the surface morphology at high magnification. From the observation analysis of Fig. 3 showed that the GO is a very thin monolayer or few-layered structures made up of folded and wrinkled graphene films. The films were thin due to the mechanical forces produced by using an ultrasonication bath. The films were wrinkled, folded and stacked by a few layers of graphene due to the strong $\pi-\pi$ interaction at the surfaces ${ }^{18}$.

The Energy Dispersive X-Ray (EDX) measurement was used to investigate the elemental and quantitative compositions of the materials. In this measurement, an accelerating voltage of $20 \mathrm{kV}$ was used with a scan time of $100 \mathrm{~s}$ per sampling area. The EDX spectrum of GO is as shown in Fig. 4 . The observation revealed the presence of Carbon (C), Oxygen (O), Aluminum (Al), Silicon (Si), Sulphur (S) and Potassium (K). The C content of the GO was valued at $51.64 \%$ and was obviously the highest as graphite is a carbon material. This was followed by $35.62 \%$ of $\mathrm{O}$ content due to the oxygen-containing functional groups produced from the oxidation process by using Hummer's method. The mass ratio of $\mathrm{O} / \mathrm{C}$ was 0.68 . Lastly, the content of $\mathrm{S}, \mathrm{Si}, \mathrm{Al}$ and $\mathrm{K}$ were reported at $7.85 \%, 2.60 \%, 1.50 \%$ and $0.79 \%$ respectively.

Thermogravimetric analysis (TGA) was used to determine the temperature at when a material was completely decomposed. The drop in the mass shows the material was undergoing the decomposition process. Based on Fig. 5 below, a TGA comparison between graphite and GO can be seen. While graphite percentage mass maintained close to $100 \%$ TGA because of a non-volatile nature, GO showed drop throughout the process mainly once the temperature hit $150{ }^{\circ} \mathrm{C}$. This finding can be related with a study done by Ref. ${ }^{19}$. According to them, the majority of the carbon atoms in GO have been converted from graphitic $\mathrm{sp}^{2}$ to a non-graphitic $\mathrm{sp}^{3}$ hybridized carbon that contains high density of defects due to the oxidation process that occurred. The defects and weaker 


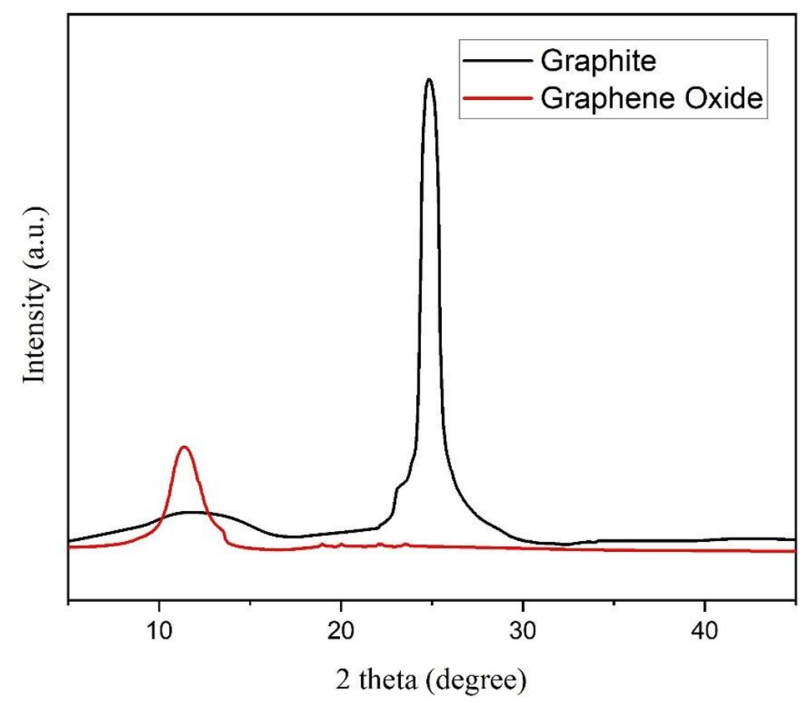

Figure 2. XRD patterns of graphite and GO deposited on $\mathrm{Si}$ with the peak of graphite observed at $2 \Theta=26.73^{\circ}$ and the peak of $\mathrm{GO}$ at $2 \mathrm{O}=11.54^{\circ}$.

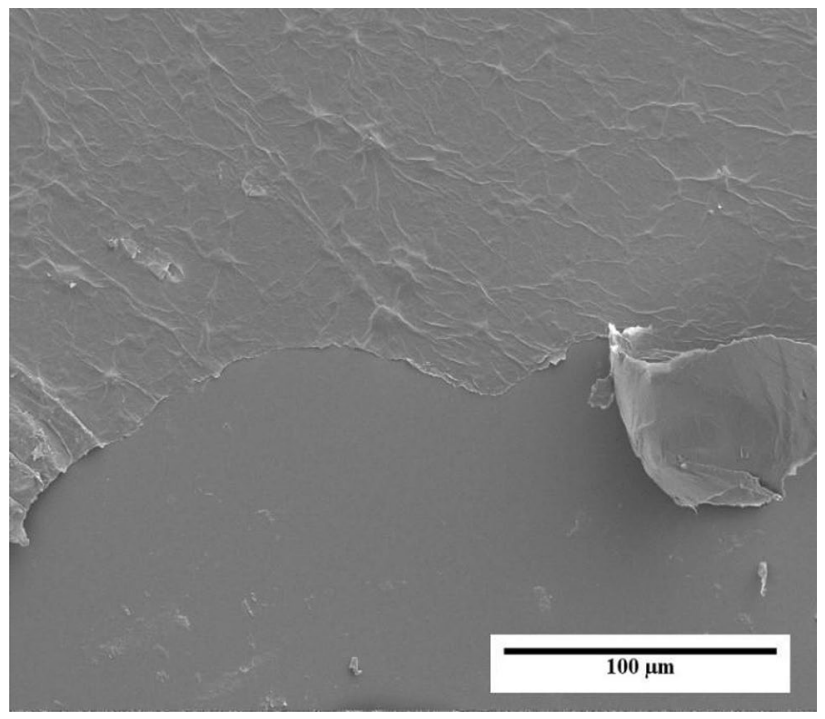

Figure 3. FESEM of thin GO monolayer made up of folded and wrinkled graphene films.

interaction between the exfoliated graphene layers cause the thermal degradation temperature to reach much faster. Hence the difference between the stability in mass percentage between graphite and GO can clearly be observed.

Cell viability and $\mathrm{pH}$ of GO. One of the components that can be taken into consideration when maintaining the solubility of GO is the $\mathrm{pH}$ of the prepared GO. According to Refs. ${ }^{20,21}$, the carboxyl groups of GO at lower $\mathrm{pH}$ are protonated, thus making the GO less hydrophilic, while at the higher $\mathrm{pH}$ of GO, the carboxyl groups are deprotonated, eventually enhance the hydrophilic features and resulting in better GO solubility. The cell membranes are semipermeable and allow selected molecules to pass through the barriers and induce changes to the biological interactions. Therefore, to distinguish the interaction between the MCF7 breast cancer cells and MCF10a normal breast cells due to the presence of GO, an observation on the effect of different $\mathrm{pH}$ of GO towards the cell viability was done. Figure 6 shows the numbers of viable MCF7 and MCF10a cells against the pH of GO after $24 \mathrm{~h}$ (as shown in Fig. 6a) and $48 \mathrm{~h}$ (as shown in Fig. 6b) incubation. After $24 \mathrm{~h}$ of incubation (i.e. incubation period) for MCF10a (Fig. 6a), the percentage number of viable cells decreased to $90.5 \%, 92.8 \%$ and $98.4 \%$ after the GO treatments with the $\mathrm{pH} 5,6$ and 7, respectively. From the percentage obtained, only a slight reduction in the cell's numbers can be seen. The $\mathrm{pH}$ value for normal cells usually ranging from $\mathrm{pH} 7.2$ to $\mathrm{pH}$ 7.5 which is in a neutral condition ${ }^{22}$. Hence, when the MCF10a surrounding was slightly acidic due to the $\mathrm{pH}$ 


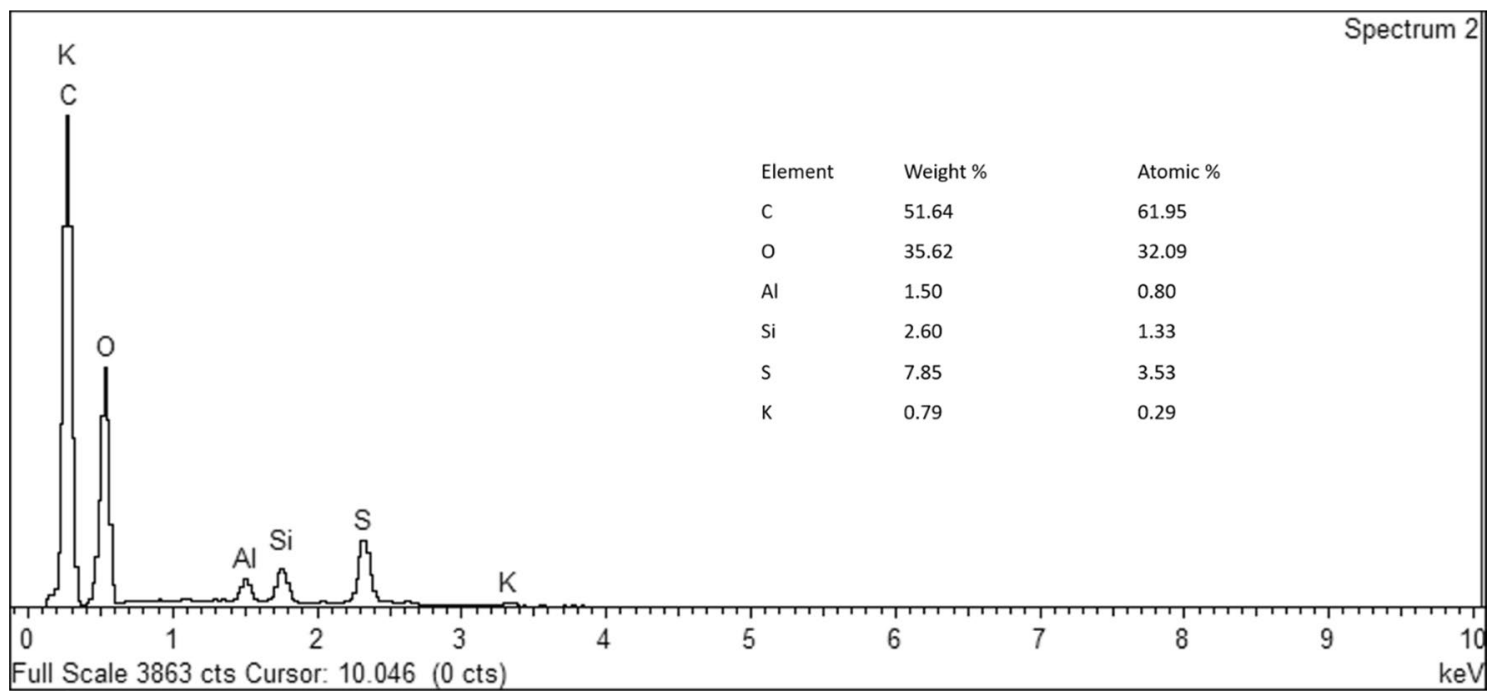

Figure 4. EDX spectra of GO deposited on Si shows the two most high atomic percentage which is Carbon (C) and Oxygen $(\mathrm{O})$ at $51.64 \%$ and $35.62 \%$ respectively.

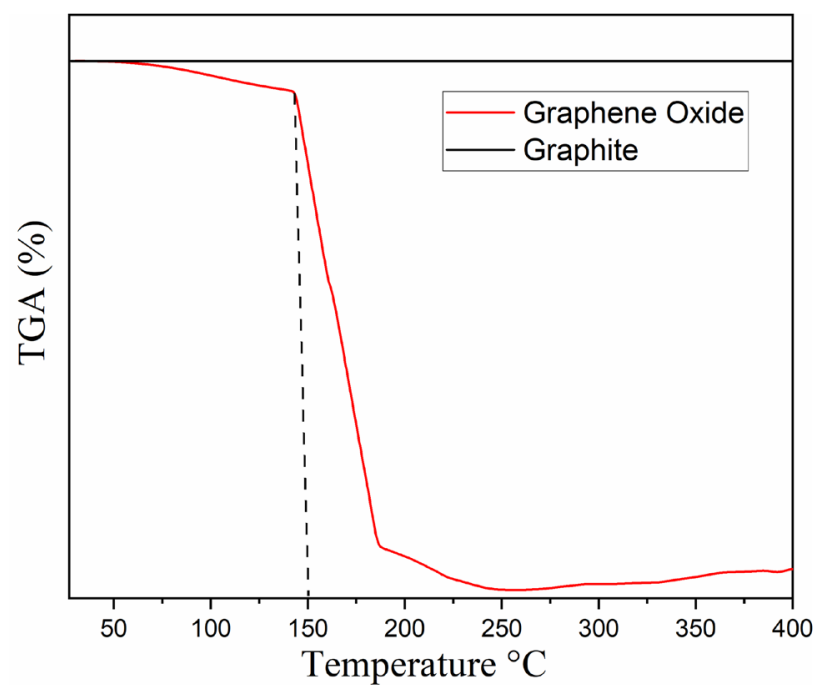

Figure 5. TGA analysis curves of graphite and graphene oxide (GO).

value of GO at $\mathrm{pH} 5$ and $\mathrm{pH} 6$, more reduction in the cell viability can be seen. Meanwhile, after $48 \mathrm{~h}$ of incubation, the cell viability increased significantly to $109.8 \%, 113.6 \%$ and $116.4 \%$, respectively at the $\mathrm{pH} 5,6$ and 7 , as compared to after $24 \mathrm{~h}$ incubation. A paper by Ref. ${ }^{23}$ discussed that normal human cells undergo proliferating on average every $24 \mathrm{~h}$. During this division timing, the cells were allowed to synchronize with the physiological process and the changes in their environment and hence suggested the best maximum effect to be measured at $24 \mathrm{~h}$ incubation period to prevent any interruption of other external factors.

As shown in Fig. 6a, the percentages of viable MCF7 cells treated with different GO pH for $24 \mathrm{~h}$ was relatively similar and were approximately $73.13 \%, 73.53 \%$ and $73.93 \%$, respectively. This result shows greater reduce in the cell viability compared to the normal breast cells MCF10a suggesting that GO gave greater effects towards the breast cancer cells MCF7 than the normal breast cells MCF10a. Plus, when the incubation period was increased to $48 \mathrm{~h}$ (as shown in Fig. 6b), the percentages of viable MCF7 cells treated with different GO pH of 5, 6 and 7 dropped further to $63.07 \%, 58.93 \%$ and $56.98 \%$, respectively. These continuous decreases with respect to the incubation time somehow only occurred for the MCF7 compared to the MCF10a and was supported by Ref. ${ }^{24}$ that stated GO have the ability to hinders the proliferation of the cancer stem cells in wide array of cancer and is not toxic to the normal pluripotent stem cells, but stimulate their differentiation into various cell types. Moreover, the GO of $\mathrm{pH} 7$ had a greater effect on the cell viability, than the GO of $\mathrm{pH} 5$, and this corresponded to the hydrophilic properties. As the $\mathrm{pH}$ increased, the hydrophilicity of $\mathrm{GO}$ also increased ${ }^{21}$. Hence, the prepared GO resulted in better solubility for better interactions with the cells. Therefore, for the next dose-dependent cell viability study, the GO of $\mathrm{pH} 7$ was selected to be tested with varying GO concentrations, as the GO of $\mathrm{pH}$ 

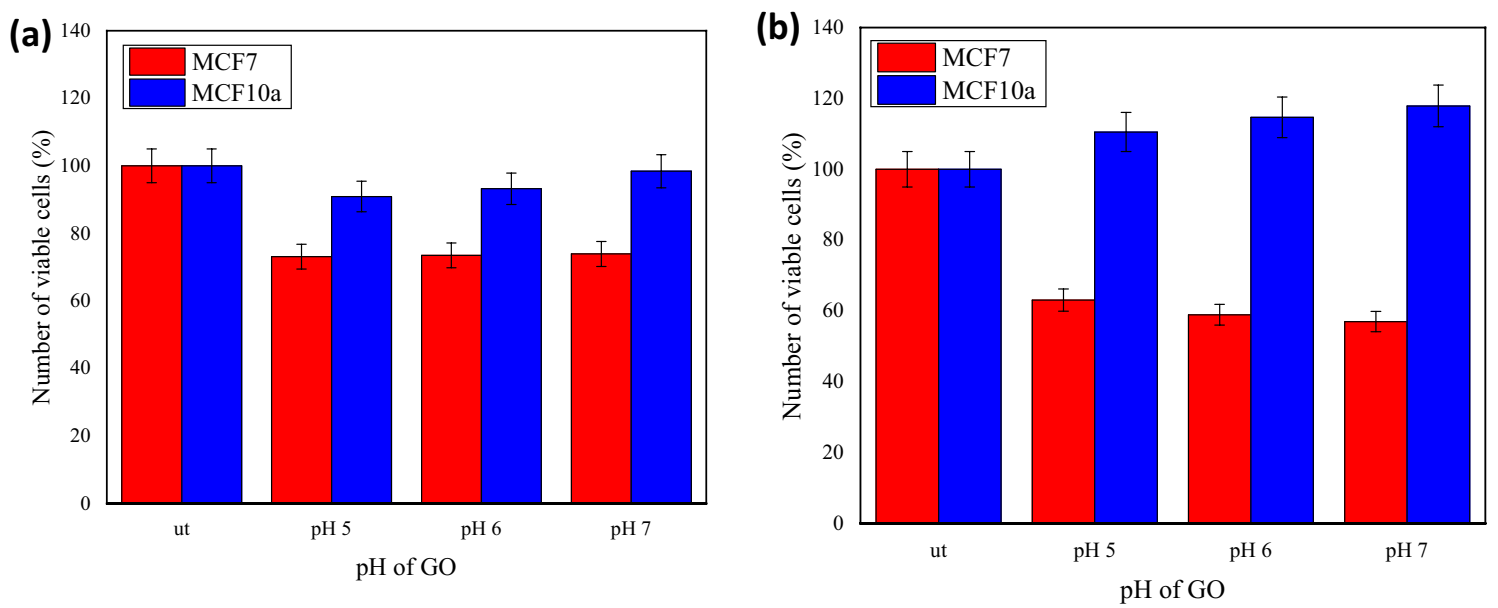

Figure 6. The comparison between the number of viable cells of MCF7 and MCF10a against pH of GO after (a) $24 \mathrm{~h} \mathrm{(b)} 48 \mathrm{~h}$. The ut represents the untreated cells or cells which were not treated with GO.
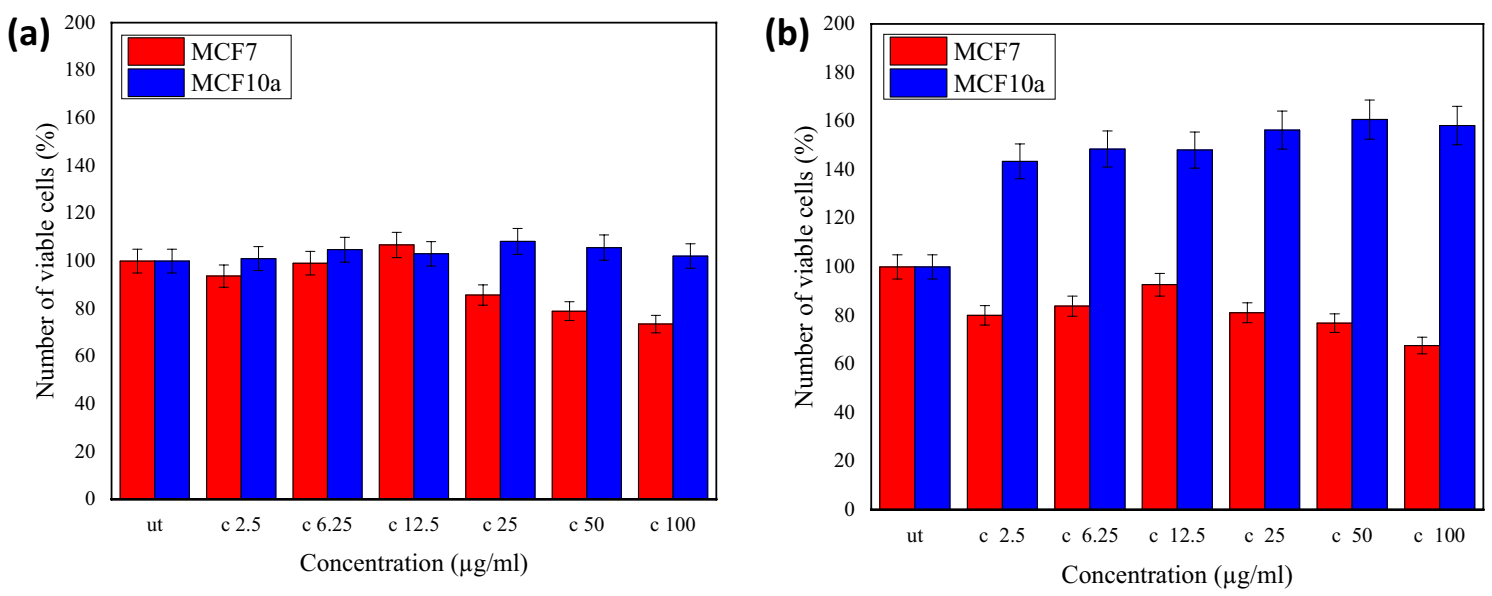

Figure 7. The comparison between the number of viable cells of MCF7 and MCF10a against concentration of $\mathrm{GO}$ after (a) $24 \mathrm{~h}$ and (b) $48 \mathrm{~h}$. The ut represents the untreated cells or cells which were not treated with GO.

7 was shown to inhibit the growth of breast cancer MCF7 cells while maintaining or increasing the viability of normal breast MCF10a cells.

For the dose-dependent cell viability study, the GO concentrations were varied into six different concentrations $(2.5,6.25,12.5,25,50$ and $100 \mu \mathrm{g} / \mathrm{mL})$ while the $\mathrm{pH}$ of $\mathrm{GO}$ was fixed at 7 . Figure 7 shows the comparison between the number of viable MCF10a and MCF7 cells against the different concentrations after $24 \mathrm{~h}$ incubation time. The graph in Fig. 7a shows a small percentage difference between the number of untreated and treated MCF10a cells. The average number of MCF10a cells varied between 1 to $7.89 \%$, as compared to the untreated MCF10a cells. Here, the value larger than $100 \%$ was inferred to the activation of MCF10a. In the case of a $48 \mathrm{~h}$ incubation period, the results, as in Fig. 7b, showed that the percentages of viable MCF10a were much larger (ca. 43.47-60.6\%), as compared to the untreated MCF10a cells. At the higher concentrations of GO ( $>25 \mu \mathrm{g} /$ $\mathrm{mL}$ ), the percentages of viable MCF10a cells were slightly larger than that of the lower GO concentrations. This increase resembled a much higher activation of MCF10a cells. Overall, the MCF10a activation does not have a strong dependency on the GO concentrations but rather is dependent on the incubation time.

In the case of GO incubation with the MCF7 cells, the data in Fig. 7a showed the number of viable cells was slightly proportional to the GO concentrations of less than $25 \mu \mathrm{g} / \mathrm{mL}$, then showed inversely proportional relation appeared for the concentrations of more than $25 \mu \mathrm{g} / \mathrm{mL}$. Moreover, at $12.5 \mu \mathrm{g} / \mathrm{mL}$, the number of viable cells was larger than $100 \%$, thus indicating the activation of cells. The results were insignificant by considering the $10 \%$ error bar. However, the GO concentrations of less than $25 \mu \mathrm{g} / \mathrm{mL}$ are not sufficient to increase the inhibition rate, similar to the study for GO reacting with the cancer cells ${ }^{25}$.

After the $48 \mathrm{~h}$ incubation period, a similar trend of data was observed. However, the difference between the number of viable MCF7 and MCF10a cells was much larger at the higher GO concentration. For example, at the GO concentration of $100 \mu \mathrm{g} / \mathrm{mL}$, the difference was ca. $30 \%$ for the $24 \mathrm{~h}$ incubation period, while it was $90 \%$ for that $48 \mathrm{~h}$, hence was proportional to the incubation time. GO increased MCF7 toxicity, while it has much lower toxicity to normal breast epithelial cells, MCF10a. One of the possible mechanisms that cause cytotoxicity effect is the eliciting of apoptosis such that the GO stimulated molecular and cellular apoptosis in cancer cells whereas 
(a)

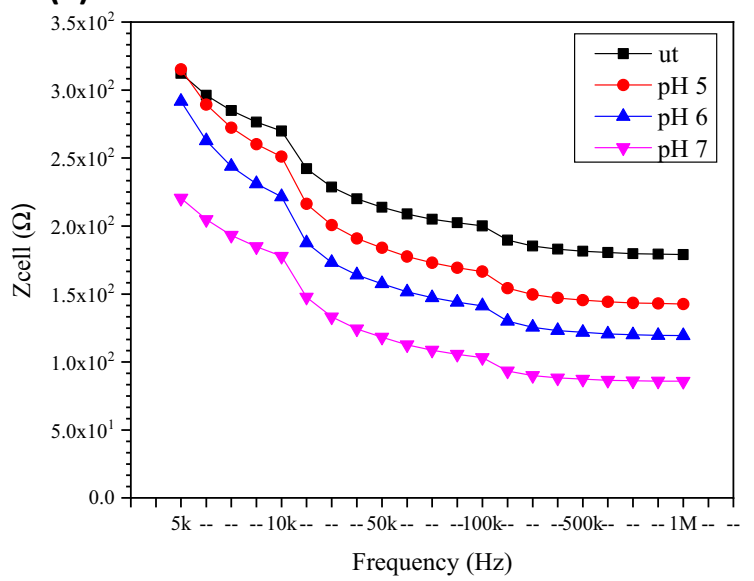

(c)

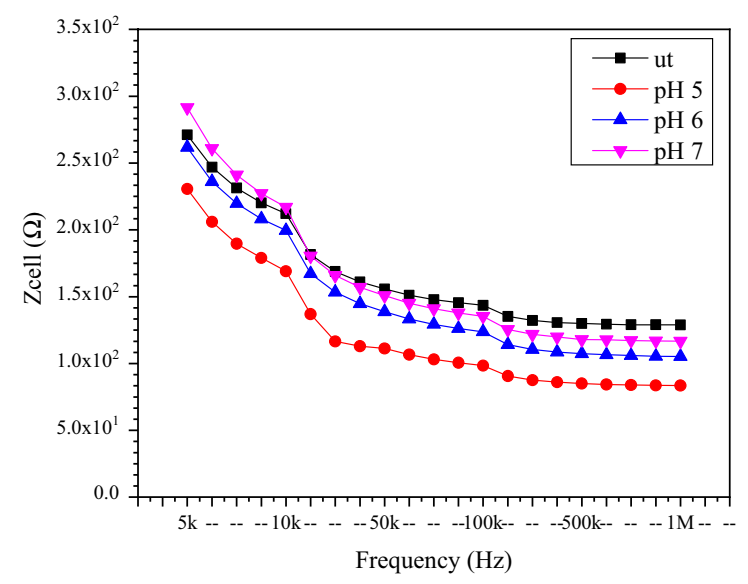

(b)

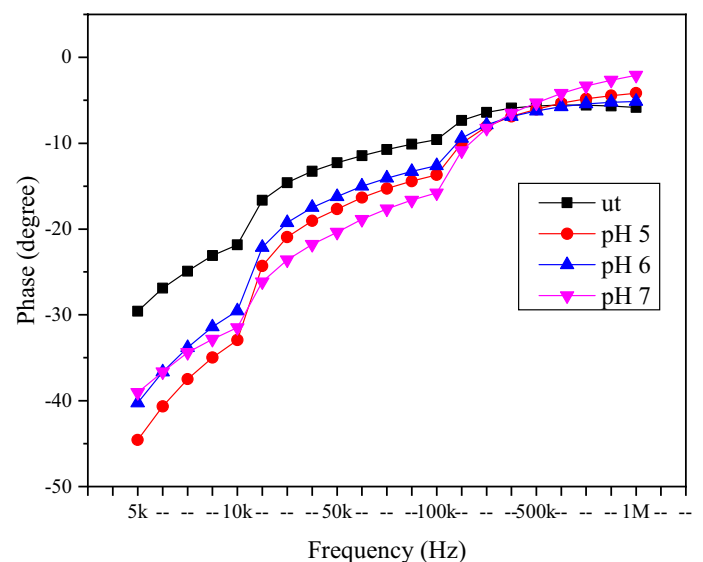

(d)

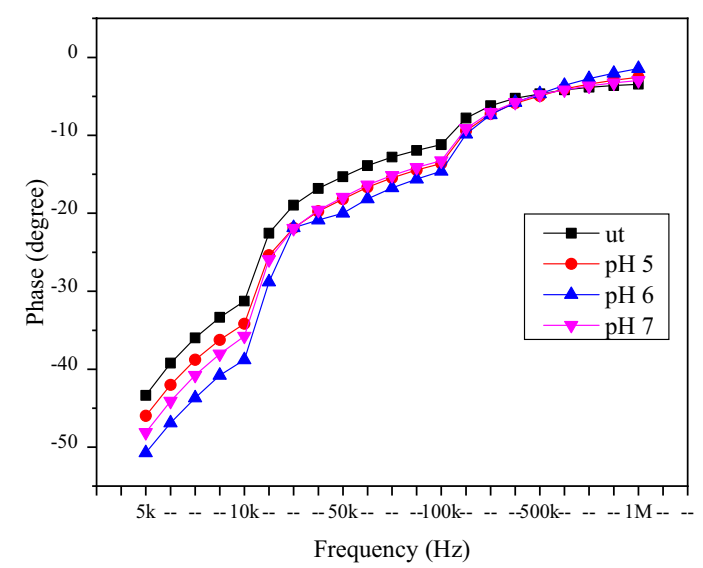

Figure 8. The electrical (a) $\mathrm{Z}_{\text {cell }}$ and (b) phase of untreated and treated breast cancer cell (MCF7) and the electrical (c) $\mathrm{Z}_{\text {cell }}$ and (d) phase of untreated and treated normal breast cell (MCF10a) with different pH of GO for $24 \mathrm{~h}$.

demonstrated low apoptosis observed in treated normal breast epithelial cells ${ }^{26}$. Nevertheless, the focus of current study is on the phenomenological characterization of MCF7 and MCF10a response to GO in terms of viability and electrical response, which paving the way to a more in-depth study such as the molecular dynamics studies that could explain the effect of GO on the two cell lines ${ }^{27}$.

Electrical responses characterization. The MCF7 and MCF10a cells, untreated and treated with different $\mathrm{GO} \mathrm{pH}$ for 24 and $48 \mathrm{~h}$ were characterized based on the electrical response. Gold interdigitated electrodes on glass substrate with $10 \mu \mathrm{m}$ gaps having initial resistance of $2.0 \times 10^{5} \Omega$ were used in this measurement. A constant value of $1 \mathrm{~V}$ was supplied to the electrode from the LCR meter (Agilent E4980 $20 \mathrm{~Hz}-2 \mathrm{MHz}$ Precision LCR (Inductance, Capacitance, Resistance) meter, USA) equipped with LabVIEW 2012 software, to obtain the electrical parameters values. The measurement was done at frequency between $20 \mathrm{~Hz}$ to $2 \mathrm{MHz}$.

The electrical impedance and resistance responses of untreated and treated MCF7 and MCF10a cells with different $p H$ of $G O$ after $24 \mathrm{~h}$. Figure 8a,b shows the electrical $\mathrm{Z}_{\text {cell }}$ and phase values from the untreated and treated MCF7 cells with different GO pH for $24 \mathrm{~h}$. From the plot, the MCF7 cells treated with GO of pH 5 showed the highest $Z_{\text {cell }}$ value, while the cells treated with $\mathrm{GO}$ of $\mathrm{pH} 7$ showed the lowest $Z_{\text {cell }}$ value. For the MCF7 cells treated with GO of pH 5, the $Z_{\text {cell }}$ value measured was $315.25 \Omega$ with phase of $-44.58^{\circ}$ at the frequency of $5 \mathrm{kHz}$ and dropped to $220.45 \Omega$ with phase of, $-39.05^{\circ}$ after the GO treatment at the $\mathrm{pH}$ of 7 . The opposite was observed in the MCF10a. From the results shown in Fig. 8c,d, the MCF10a cells treated with GO at the pH of 7 produce highest $\mathrm{Z}_{\text {cell }}$ and cells treated with GO at $\mathrm{pH} 5$ show the lowest impedance. The $\mathrm{Z}_{\text {cell }}$ and phase measure at $5 \mathrm{kHz}$ for MCF10a treated with GO at $\mathrm{pH} 7$ was $291.52 \Omega$ with a phase of $-48.10^{\circ}$, while the MCF10a cells treated with GO at the $\mathrm{pH}$ of 5 at the same frequency showed the lower $\mathrm{Z}_{\text {cell }}$ value of $230.58 \Omega$ with a phase of $-45.98^{\circ}$. The overall value of measured $Z_{\text {cell }}$ of the MCF7 was slightly higher than the measured $Z_{\text {cell }}$ of the MCF10a with decreasing trend as frequency increased observed in both samples. The phase for all samples was also measured in the negative values. The negative phase was due to the characteristic of the cell membranes which is insulative causing it to have capacitive effect. 


\begin{tabular}{|c|c|c|c|c|}
\hline \multirow[b]{2}{*}{ pH of GO } & \multicolumn{2}{|l|}{ MCF7 } & \multicolumn{2}{|l|}{ MCF10a } \\
\hline & $\begin{array}{l}\text { Resistance of component, } \\
\mathrm{R}_{\text {cell }}(\Omega)\end{array}$ & $\begin{array}{l}\text { Capacitance of component, } \\
\mathrm{C}_{\text {cell }}(\mathrm{nF})\end{array}$ & $\begin{array}{l}\text { Resistance of component, } \\
\mathbf{R}_{\text {cell }}(\Omega)\end{array}$ & $\begin{array}{l}\text { Capacitance of component, } \\
\mathrm{C}_{\text {cell }}(\mathrm{nF})\end{array}$ \\
\hline ut & 4732.90 & 775.0 & 2467.20 & 710.0 \\
\hline pH 5 & 5370.97 & 235.0 & 4819.82 & 330.0 \\
\hline pH 6 & 4818.53 & 276.0 & 5010.24 & 329.0 \\
\hline pH 7 & 3857.77 & 814.0 & 6398.32 & 267.0 \\
\hline
\end{tabular}

Table 1. The resistance and capacitance of MCF7 and MCF10a before and after were treated with different $\mathrm{pH}$ of GO for 24 h incubation time. ut: Untreated cells or cells which was not treated with GO.

As stated by Ref. ${ }^{12}$, without the cells, the $\mathrm{Z}_{\text {cell }}$ of the system can only come from the very low electrode capacitance $\left(\mathrm{C}_{\mathrm{dl}}\right)$ and the solution resistance $\left(\mathrm{R}_{\text {sol }}\right)$. For the MCF7 medium (RPMI), the $\mathrm{R}_{\text {sol }}$ value was $2.49 \mathrm{k} \Omega$ with the $\mathrm{C}_{\mathrm{dl}}$ equals to $989 \mathrm{nF}$, while for the MCF10a medium (DMEM), the $\mathrm{R}_{\text {sol }}$ value was $1.63 \mathrm{k} \Omega$ with the $\mathrm{C}_{\mathrm{dl}}$ equals to $1420 \mathrm{nF}$. After dropping the treated and untreated cells onto the electrode surface, the $\mathrm{Z}_{\text {cell }}$ of the attached cells is modelled as the capacitance component $\left(\mathrm{C}_{\text {cell }}\right)$ and the resistance component $\left(\mathrm{R}_{\text {cell }}\right)^{12,28}$.

Table 1 shows the $\mathrm{R}_{\text {cell }}$ and $\mathrm{C}_{\text {cell }}$ of untreated and treated MCF7 and MCF10a with different $\mathrm{pH}$ of GO for $24 \mathrm{~h}$. For the untreated cells, the MCF7 produces $\mathrm{R}_{\text {cell }}$ value $(4732.9 \Omega)$ higher than MCF10a $(2467.2 \Omega)$ with $\mathrm{C}_{\text {cell }}$ value of $775 \mathrm{nF}$ and $710 \mathrm{nF}$ respectively. The MCF7 shows decreased in $\mathrm{R}_{\text {cell }}$ and increased in $\mathrm{C}_{\text {cell }}$ value as the $\mathrm{pH}$ was increased from 5 to 7 . The reverse was observed in the MCF10a where the value of $\mathrm{R}_{\text {cell }}$ increased and $\mathrm{C}_{\text {cell }}$ decreased with increasing $\mathrm{pH}$ value. The $\mathrm{R}_{\text {cell }}$ value can be attributed to a few factors such as cell viability, cell types and $\mathrm{pH}$ of the solution. For MCF7 the decreasing trend in the $\mathrm{R}_{\text {cell }}$ as the $\mathrm{pH}$ of GO increase was attributed mostly due to the $\mathrm{pH}$ of the solution as the difference in cell viability between $\mathrm{pH}$ was not differ by much. As for the MCF10a, the cell viability increased slightly with increasing $\mathrm{pH}$ of the GO. Cell membranes have insulating behavior. The increase in cell numbers will contribute to the increase of $\mathrm{R}_{\text {cell }}$ as the insulating comportment of the membranes reduces the current flow. This will also contribute to decline in the capacitance values due to the increased number of highly insulating cell membranes of viable cells that contributed to the increasing $\mathrm{Z}_{\text {cell }}$, as the capacitance was inversely related to the impedance ${ }^{12,28-30}$.

The results of $Z_{\text {cell }}$ (as shown in Fig. 8) and resistance (as shown in Table 1) were compared with the number of viable cells (as shown in Fig. 6). The findings demonstrated that the MCF7 breast cancer cells had higher cell viability and lower resistance value as the $\mathrm{pH}$ increased, while the MCF10a also showed a similar increasing trend in cell viability and resistance value as the $\mathrm{pH}$ increased. It has been verified by Ref. ${ }^{31}$ that the smaller gaps between the cells and electrodes led to better sensitivity in the cells' electrical impedance signals and resistances.

The electrical impedance and resistance responses of untreated and treated MCF7 and MCF10a cells with different $\mathrm{pH}$ of $\mathrm{GO}$ after $48 \mathrm{~h}$. Figure 9 shows the electrical $\mathrm{Z}_{\text {cell }}$ and phase ranging over the frequency ranging $5 \mathrm{kHz}$ to $1 \mathrm{MHz}$ for untreated and treated MCF7 and MCF10a with different GO pH for incubation period of $48 \mathrm{~h}$. The results for both cells shows that the $\mathrm{Z}_{\text {cell }}$ decreased as the frequency increased and it converged at the higher frequencies. According to Ref. ${ }^{12}$, this condition was due to the frequency dependent characteristics, as calculated according to Eq. (1). At $5 \mathrm{kHz}$, for MCF7 the $\mathrm{Z}_{\text {cell }}$ measure decreased from $191.01 \Omega$ with phase of $-59.97^{\circ}$ after the treatment with GO of pH 5 to $162.30 \Omega$ with phase of $-55.14^{\circ}$ after the treatment with GO of pH 7. Meanwhile, for MCF10a at the same frequency, the $Z_{\text {cell }}$ increased from $131.39 \Omega$ with the phase of $-47.46^{\circ}$ after the treatment with GO of pH 5 to $170.29 \Omega$ with the phase of $-57.70^{\circ}$ after the treatment with GO of pH 7. The value of measured $Z_{\text {cell }}$ of the MCF7 was generally higher than the measured $Z_{\text {cell }}$ of the MCF10a. It was also evident that only small $\mathrm{Z}_{\text {cell }}$ variation was observed between the ut and sample with different $\mathrm{pH}$ value. The phase measure for all samples was in the negative region corresponding to the capacitive behavior of the cell membranes and could be considered as inherent characteristics of cell membranes which act as dielectric layer.

The $\mathrm{R}_{\text {cell }}$ and $\mathrm{C}_{\text {cell }}$ for both the treated MCF7 and MCF10a cells were also compared, and the results are as tabulated in Table 2 . The $\mathrm{R}_{\text {cell }}$ value for MCF7 cells was the lowest at $3.23 \mathrm{k} \Omega$, with the $\mathrm{C}_{\text {cell }}$ equals to $673 \mathrm{nF}$, while the $\mathrm{R}_{\text {cell }}$ value MCF10a was the highest at $3.59 \mathrm{k} \Omega$, with the $\mathrm{C}_{\text {cell }}$ equals to $847 \mathrm{nF}$, after the treatment with $\mathrm{GO}$ of $\mathrm{pH}$ 7. The result for the $\mathrm{Z}_{\text {cell }}$ (as shown in Fig. 9) and $\mathrm{R}_{\text {cell }}$ (as shown in Table 2) were compared with the number of viable cells (as shown in Fig. 6).

From the results it was observed that the MCF10a has higher $\mathrm{C}_{\text {cell }}$ as compared to MCF7 at respective $\mathrm{pH}$ of GO. This could be due to the lower capacitive behavior of the cell membrane for metastatic grade cancer, which could be caused by their low sterol and phospholipid contents ${ }^{32}$. The irregular shape of MCF7 as compared to MCF10a can cause it to become less inflexible, which contributes to lower polarization which also led to lower capacitance value ${ }^{33}$.

It was also observed that the MCF7 has higher $\mathrm{R}_{\text {cell }}$ value decreased as $\mathrm{pH}$ value increased while for MCF10a the $\mathrm{R}_{\text {cell }}$ increases as $\mathrm{pH}$ value increased. This can be related to the viability of the cells after $48 \mathrm{~h}$. In MCF7 cell viability reduced to $56.98 \%$ from $63.07 \%$ as $\mathrm{pH}$ of GO increased from 5 to 7 . In comparison to MCF10a in which the cell viability improves from 109.8 to $116.4 \%$ cells viability. Cell membrane is made up of a highly mobile lipid molecule bilayer that is an electrically insulator ${ }^{34}$. Having more cells available will further increase resistance. The more cells available will further decrease the gap between the highly insulating cell membranes of viable cells with the electrode surface and the decreased capacitance ${ }^{35}$. 
(a)

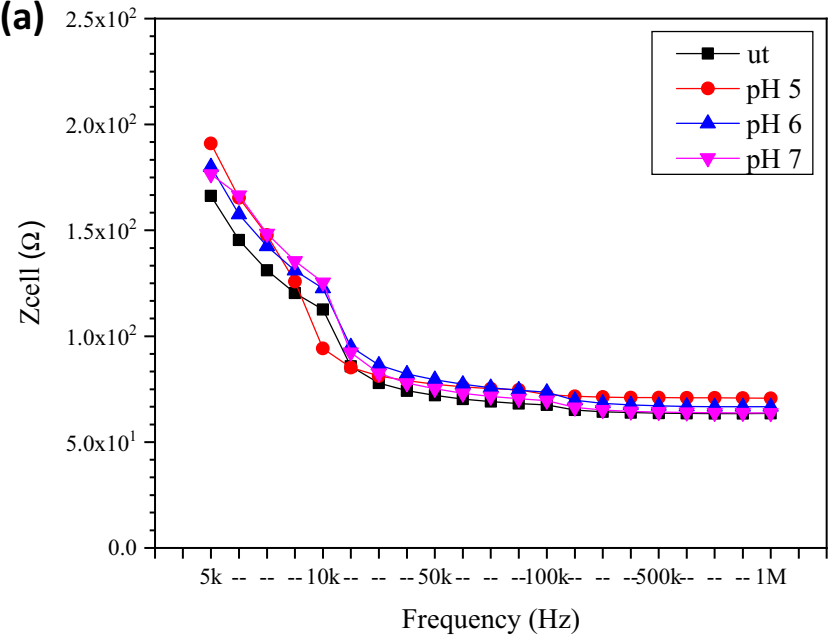

(c)

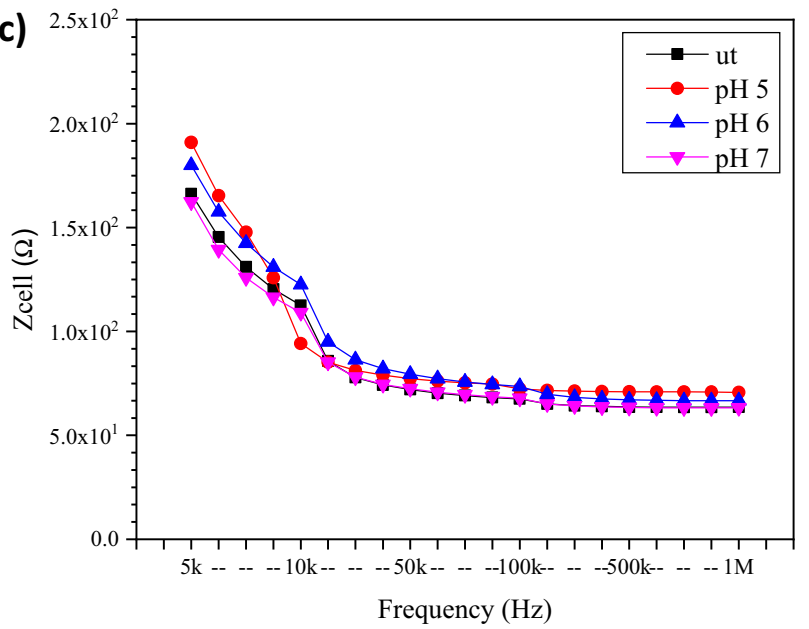

(b)

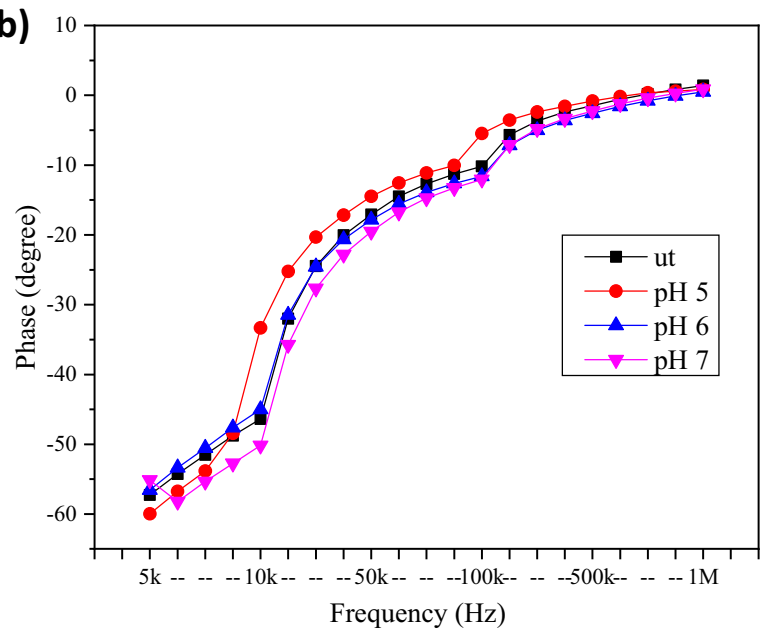

(d)

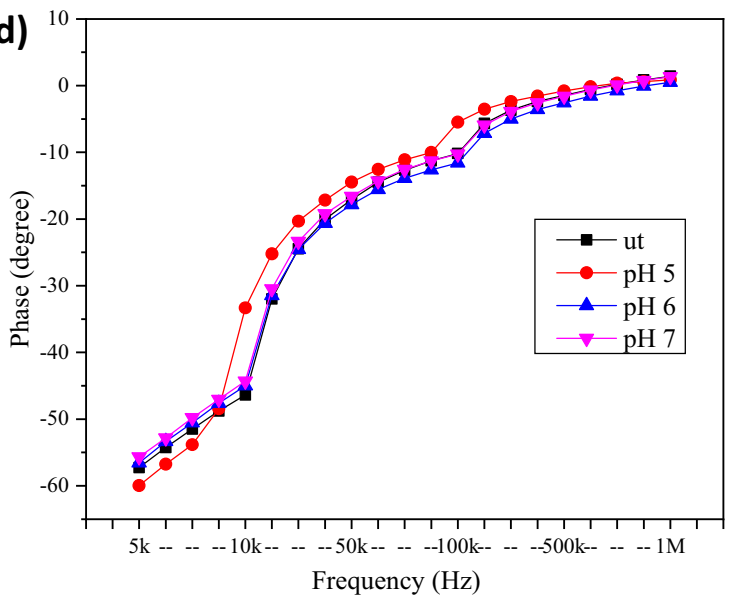

Figure 9. The electrical (a) $Z_{\text {cell }}$ and (b) phase of untreated and treated breast cancer cell (MCF7) and the (c) $\mathrm{Z}_{\text {cell }}$ and (d) phase of untreated and treated normal breast cell (MCF10a) with different pH of GO for $48 \mathrm{~h}$.

\begin{tabular}{|l|l|l|l|l|}
\hline & \multicolumn{2}{|l|}{ MCF7 } & MCF10a \\
\cline { 2 - 5 } $\mathbf{p}$ pH of GO & $\begin{array}{l}\text { Resistance of component, } \\
\mathbf{R}_{\text {cell }}(\boldsymbol{\Omega})\end{array}$ & $\begin{array}{l}\text { Capacitance of component, } \\
\mathbf{C}_{\text {cell }}(\mathbf{n F})\end{array}$ & $\begin{array}{l}\text { Resistance of component, } \\
\mathbf{R}_{\text {cell }}(\boldsymbol{\Omega})\end{array}$ & $\begin{array}{l}\text { Capacitance of component, } \\
\mathbf{C}_{\text {cell }}(\mathbf{n F})\end{array}$ \\
\hline ut & 2944.70 & 1140.0 & 2427.30 & 1130.0 \\
\hline pH 5 & 3319.37 & 463.0 & 2350.95 & 1240.0 \\
\hline pH 6 & 3257.15 & 642.0 & 2454.77 & 1170.0 \\
\hline pH 7 & 3226.02 & 673.0 & 3589.18 & 847.0 \\
\hline
\end{tabular}

Table 2. The resistance and capacitance of MCF7 and MCF10a before and after treated with different $\mathrm{pH}$ of GO for $48 \mathrm{~h}$ incubation time. ut: Untreated cells or cells which was not treated with GO.

The electrical impedance and resistance responses of untreated and treated MCF7 and MCF10a cells with different concentrations of GO after $24 \mathrm{~h}$. The dose dependent GO effects on the MCF7 and MCF10a cells are shown in Fig. 10a,b. The findings showed that the $Z_{\text {cell }}$ of MCF7 cells rose after treatment with $12.5 \mu \mathrm{g} / \mathrm{mL}$ of GO at the $\mathrm{pH}$ of 7. However, the $Z_{\text {cell }}$ of MCF7 cells decreased as the GO concentrations increased. At a frequency of $5 \mathrm{kHz}$, the electrical $Z_{\text {cell }}$ of the MCF7 cells treated with $12.5 \mu \mathrm{g} / \mathrm{mL}$ of GO was $425.27 \Omega$ with a phase of $-44.78^{\circ}$, while for the MCF7 cells treated with $100 \mu \mathrm{g} / \mathrm{mL}$ of GO, the electrical $Z_{\text {cell }}$ was $220.45 \Omega$ with a phase of $-39.05^{\circ}$. From Fig. $10 \mathrm{c}$,d, the MCF10a cells treated with $25 \mu \mathrm{g} / \mathrm{mL}$ of GO showed the highest $Z_{\text {cell }}$ value of $345.03 \Omega$ with a phase of $-34.13^{\circ}$, while the MCF10a cells treated with $2.5 \mu \mathrm{g} / \mathrm{mL}$ of GO showed the lowest $Z_{\text {cell }}$ of $210.27 \Omega$ with a phase of $-62.83^{\circ}$ at $5 \mathrm{kHz}$.

An increasing $Z_{\text {cell }}$ value shows the increasing resistance of the cells. For the MCF7 treated with $12.5 \mu \mathrm{g} / \mathrm{mL}$ of GO, the highest $R_{\text {cell }}$ value was $7.73 \mathrm{k} \Omega$ with the $\mathrm{C}_{\text {cell }}$ equals to $256 \mathrm{nF}$. Meanwhile, for the MCF10a treated with $25 \mu \mathrm{g} / \mathrm{mL}$ of GO, the highest resistance value was $6.62 \mathrm{k} \Omega$ with the $\mathrm{C}_{\text {cell }}$ equals to $225 \mathrm{nF}$. The resistance 
(a)

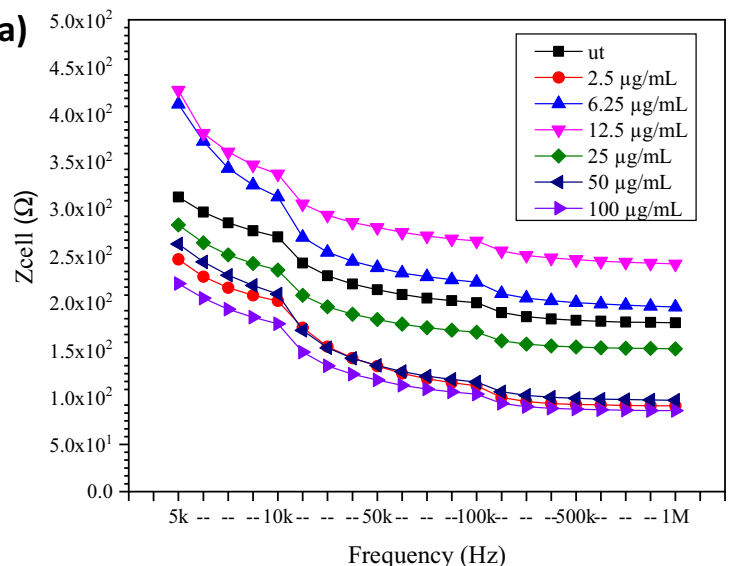

(c)

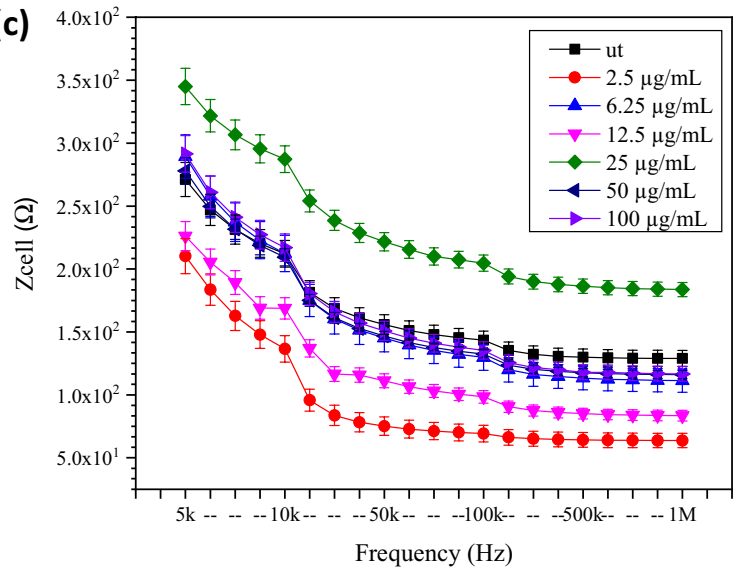

(b)

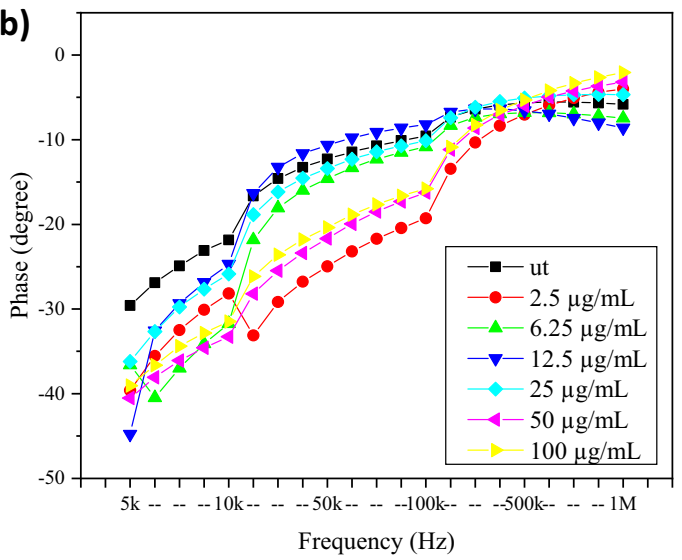

(d)

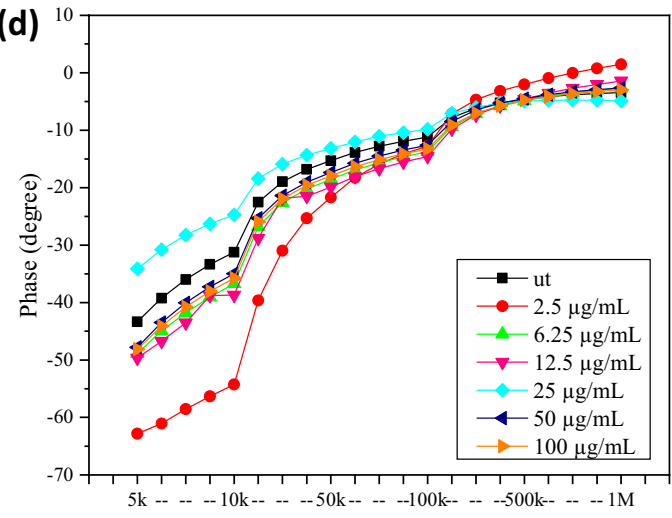

Frequency (Hz)

Figure 10. The electrical (a) $Z_{\text {cell }}$ and (b) phase of untreated and treated breast cancer cell (MCF7) and the (c) $\mathrm{Z}_{\text {cell }}$ and (d) phase of untreated and treated normal breast cell (MCF10a) with different concentration of GO for $24 \mathrm{~h}$.

\begin{tabular}{|c|c|c|c|c|}
\hline \multirow[b]{2}{*}{ Concentration of $\mathrm{GO}(\mu \mathrm{g} / \mathrm{mL})$} & \multicolumn{2}{|l|}{ MCF7 } & \multicolumn{2}{|l|}{ MCF10a } \\
\hline & $\begin{array}{l}\text { Resistance of component, } \mathbf{R}_{\text {cell }} \\
(\Omega)\end{array}$ & $\begin{array}{l}\text { Capacitance of component, } \mathrm{C}_{\text {cell }} \\
(\mathrm{nF})\end{array}$ & $\begin{array}{l}\text { Resistance of component, } R_{\text {cell }} \\
(\Omega)\end{array}$ & $\begin{array}{l}\text { Capacitance of component, } \mathrm{C}_{\text {cell }} \\
(\mathrm{nF})\end{array}$ \\
\hline ut & 4732.90 & 775.0 & 2467.20 & 710.0 \\
\hline 2.5 & 4497.88 & 716.0 & 4819.82 & 935.0 \\
\hline 6.25 & 4818.53 & 276.0 & 6219.79 & 288.0 \\
\hline 12.5 & 7730.03 & 256.0 & 5078.66 & 687.0 \\
\hline 25 & 4451.92 & 589.0 & 6621.56 & 225.0 \\
\hline 50 & 3257.91 & 640.0 & 5835.85 & 261.0 \\
\hline 100 & 3857.77 & 814.0 & 6398.32 & 267.0 \\
\hline
\end{tabular}

Table 3. The resistance and capacitance of MCF7 and MCF10a before and after treated with different concentrations of GO for $24 \mathrm{~h}$ incubation time. ut: Untreated cells or cells which was not treated with GO.

and capacitance results of MCF7 and MCF10a untreated and treated with different GO concentrations for $24 \mathrm{~h}$ were summarized in Table 3.

The $\mathrm{Z}_{\text {cell }}$ and resistance results trends were correlated to the number of viable cells trend, as shown in Fig. 7a. The highest number of viable MCF7 cells was recorded after the treatment with $12.5 \mu \mathrm{g} / \mathrm{mL}$ of GO, while the lowest was recorded after the treatment with $100 \mu \mathrm{g} / \mathrm{mL}$ of GO. Meanwhile, the highest number of viable MCF10a was recorded after the treatment with $25 \mu \mathrm{g} / \mathrm{mL}$ of GO, while the lowest was recorded after the treatment with $2.5 \mu \mathrm{g} / \mathrm{mL}$ of GO. The trend was comparable to the findings reported by Ref. ${ }^{35}$. The study observed that the $\mathrm{Z}_{\text {cell }}$ and resistance increased to correspond with the decreased gap between the highly insulating cell membranes of viable cells with the electrode surface; hence it was related to the decreased capacitance. When the capacitance decreased, the $\mathrm{Z}_{\text {cell }}$ value increased, similar to the resistance value. 

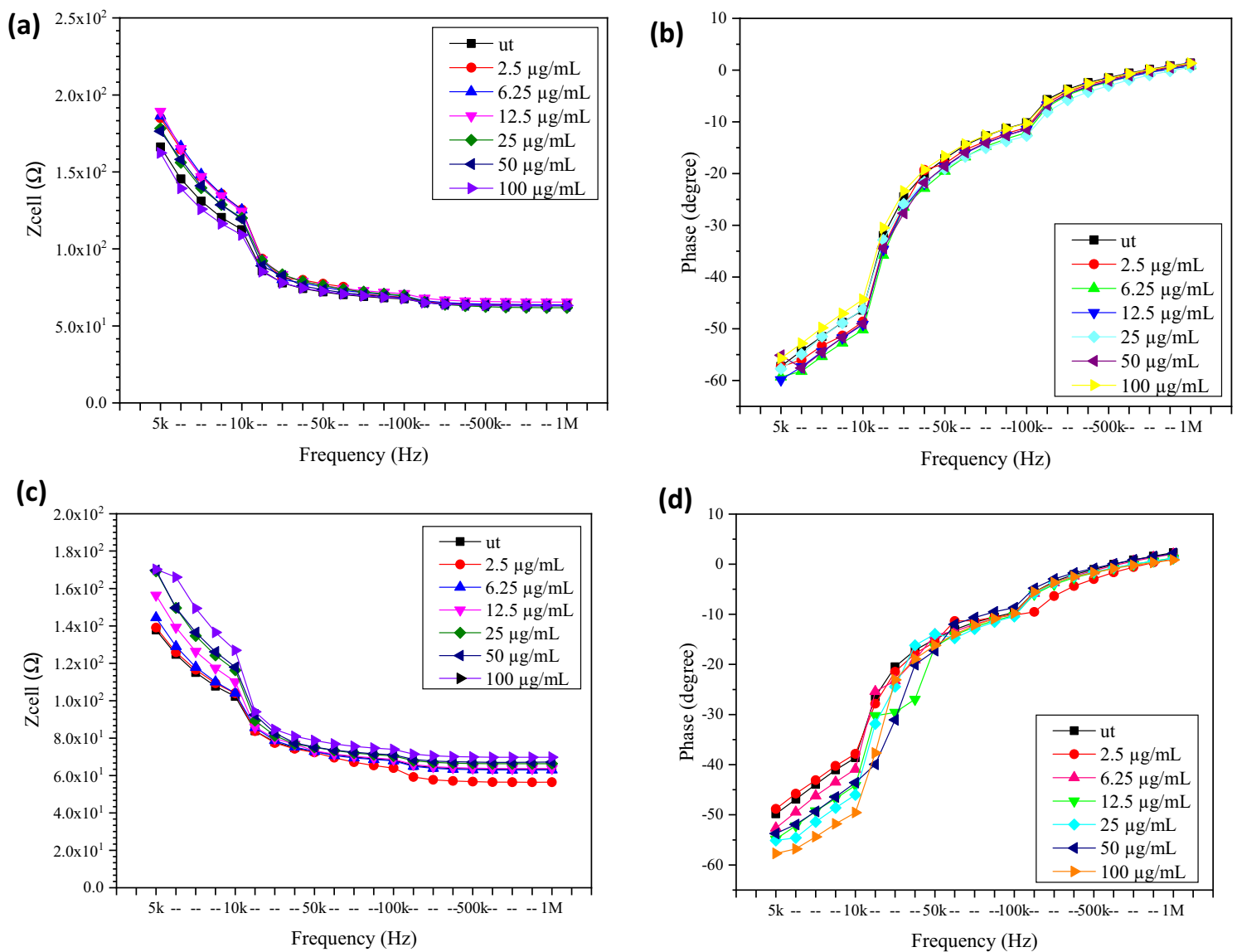

Figure 11. The electrical (a) $Z_{\text {cell }}$ and (b) phase of untreated and treated breast cancer cell (MCF7) and the (c) $\mathrm{Z}_{\text {cell }}$ and (d) phase of untreated and treated normal breast cell (MCF10a) with different concentration of GO for $48 \mathrm{~h}$.

\begin{tabular}{|c|c|c|c|c|}
\hline \multirow[b]{2}{*}{ Concentration of GO $(\mu \mathrm{g} / \mathrm{mL})$} & \multicolumn{2}{|l|}{ MCF7 } & \multicolumn{2}{|l|}{ MCF10a } \\
\hline & $\begin{array}{l}\text { Resistance of component, } R_{\text {cell }} \\
(\Omega)\end{array}$ & $\begin{array}{l}\text { Capacitance of component, } \mathrm{C}_{\text {cell }} \\
(\mathrm{nF})\end{array}$ & $\begin{array}{l}\text { Resistance of component, } R_{\text {cell }} \\
(\Omega)\end{array}$ & $\begin{array}{l}\text { Capacitance of component, } \mathrm{C}_{\text {cell }} \\
(\mathrm{nF})\end{array}$ \\
\hline ut & 2944.70 & 1140.0 & 2427.30 & 1130.0 \\
\hline 2.5 & 3648.55 & 631.0 & 2433.77 & 1141.0 \\
\hline 6.25 & 3673.58 & 572.0 & 2509.06 & 1120.0 \\
\hline 12.5 & 3684.56 & 563.0 & 2969.99 & 951.0 \\
\hline 25 & 3486.65 & 601.0 & 2996.11 & 937.0 \\
\hline 50 & 3276.41 & 628.0 & 3415.25 & 884.0 \\
\hline 100 & 3226.02 & 673.0 & 3589.18 & 847.0 \\
\hline
\end{tabular}

Table 4. The resistance and capacitance of MCF7 and MCF10a before and after treated with different concentrations of GO for $48 \mathrm{~h}$ incubation time. ut: Untreated cells or cells which were not treated with GO.

The electrical impedance and resistance responses of untreated and treated MCF7 and MCF10a cells with different concentrations of $G O$ after $48 \mathrm{~h}$. Figure 11 shows the electrical $\mathrm{Z}_{\text {cell }}$ and phase of MCF7 and MCF10a untreated or treated with different GO concentrations, with a longer incubation period of $48 \mathrm{~h}$. At a frequency below $500 \mathrm{kHz}$, the $\mathrm{Z}_{\text {cell }}$ decreased as the frequency increased. In contrast, it intersected and became stable at frequencies higher than $500 \mathrm{kHz}$. According to Ref. ${ }^{12}$, this condition was due to the frequency-dependent characteristics, as calculated according to Eq. (1). For the MCF7 treated with $100 \mu \mathrm{g} / \mathrm{mL}$ of GO, the lowest $Z_{\text {cell }}$ was 162.30 $\Omega$, with the phase of $-55.68^{\circ}$, while the highest $Z_{\text {cell }}$ was $189.24 \Omega$, with the phase of $-59.87^{\circ}$ at the frequency of $5 \mathrm{kHz}$. On the other hand, for the MCF10a, the $\mathrm{Z}_{\text {cell }}$ increased from $139.13 \Omega$ with the phase of $-48.82^{\circ}$ to 170.29 $\Omega$ with the phase of $-57.70^{\circ}$ at $5 \mathrm{kHz}$ after treated with a higher $\mathrm{GO}$ concentration of $100 \mu \mathrm{g} / \mathrm{mL}$.

Table 4 shows the resistance $\left(\mathrm{R}_{\text {cell }}\right)$ and capacitance $\left(\mathrm{C}_{\text {cell }}\right)$ of MCF7 and MCF10a before and after incubation treatment with different GO concentrations for $48 \mathrm{~h}$. For the MCF7, the lowest $\mathrm{R}_{\text {cell }}$ value was $3.23 \mathrm{k} \Omega$, with the 
$\mathrm{C}_{\text {cell }}$ equals to $673 \mathrm{nF}$ after treatment with $100 \mu \mathrm{g} / \mathrm{mL}$ of $\mathrm{GO}$, while the highest $\mathrm{R}_{\text {cell }}$ value was $3.68 \mathrm{k} \Omega$, with the $\mathrm{C}_{\text {cell }}$ equals to $563 \mathrm{nF}$ after treatment with $12.5 \mu \mathrm{g} / \mathrm{mL}$ of GO.

The $\mathrm{Z}_{\text {cell }}$ and resistance trends of MCF7 were similar for 24 and $48 \mathrm{~h}$, as compared to the results presented in Fig. 9 and Table 3 . Thus, the results proved that the $Z_{\text {cell }}$ and resistance were increased linearly with an increasing amount of highly insulating viable cell membrane on the IDEs, subsequently leading to a decrease in the capacitance. These findings were in agreement with the findings of Ref. ${ }^{12}$. Meanwhile, the $\mathrm{R}_{\text {cell }}$ increased steadily from 2.43 to $3.59 \mathrm{k} \Omega$, with the $\mathrm{C}_{\text {cell }}$ equals to $1143 \mathrm{nF}$ and $847 \mathrm{nF}$ for MCF10a after $100 \mu \mathrm{g} / \mathrm{mL}$ of GO treatment. It showed that the resistance trend was corresponding to the impedance, as shown in Fig. 11, and was comparable with the trend for the number of viable MCF7 and MCF10a cells, as shown in Fig. 7b.

\section{Conclusion}

For this research, a few layers of GO, with an average size of 0.56-0.96 $\mu \mathrm{m}$ and an average thickness of 1.24-1.32 nm, were successfully produced by using the Hummer's method. Then, the GO was further synthesized and characterized by using the Raman spectroscopy, XRD spectroscopy, FESEM, EDX spectroscopy and TGA analysis. The cell viability for both the MCF7 and MCF10a before and after treatment with GO was successfully determined by using the PrestoBlue cell viability assay. After treating both the MCF7 and MCF10a cells with three different $\mathrm{pH}$ (e.g., $\mathrm{pH} \mathrm{5,6}$ and 7), it was that when the GO pH increased to 7, the number of MCF7 viable cells was decreased, while the number of MCF10a viable cells was maintained at $24 \mathrm{~h}$ incubation time. Also, the number of MCF7 viable cells was further decreased with the increasing number of MCF10a viable cells at $48 \mathrm{~h}$ incubation time. Hence, it can be deduced that the GO of $\mathrm{pH} 7$ was the most suitable $\mathrm{pH}$ to inhibit the MCF7 proliferation compared to $\mathrm{pH} 5$ and $\mathrm{pH}$, with the optimum incubation period at $24 \mathrm{~h}$. In terms of the dosedependent interaction between cells and GO, the concentration of GO was varied into six different concentrations (e.g., 2.5, 6.25, 12.5, 25, 50 and $100 \mu \mathrm{g} / \mathrm{mL}$ ). For the electrical characterization part, the electrical properties of MCF7 and MCF10a cells before and after exposures to GO were successfully demonstrated by using $10 \mu \mathrm{m}$-gaps gold interdigitated electrodes connected to the LCR meter. In conclusion, the trend showing the number of viable cells was comparable with the capacitance, impedance, and resistance results. Thus, it was proven that the capacitance reduction was due to the increase in highly insulating MCF7 and MCF10a cells membrane. When dropped on the electrode surface, the highly insulated cells membrane caused an increase in electrical $\mathrm{Z}_{\text {cell }}$ and resistance. In conclusion, the electrical characterization and cell viability analyses of breast cancer cells using the GO deposited on IDE were successful.

Received: 1 August 2021; Accepted: 7 October 2021

Published online: 19 October 2021

\section{References}

1. Barahuie, F. et al. Graphene oxide as a nanocarrier for controlled release and targeted delivery of an anticancer active agent, chlorogenic acid. Mater. Sci. Eng. C 74, 177-185 (2017).

2. Kakran, M., Sahoo, G. N., Bao, H., Pan, Y. \& Li, L. Functionalized graphene oxide as nanocarrier for loading and delivery of ellagic acid. Curr. Med. Chem. 18, 4503-4512 (2011).

3. Fu, P. P., Xia, Q., Hwang, H. M., Ray, P. C. \& Yu, H. Mechanisms of nanotoxicity: Generation of reactive oxygen species. J. Food Drug Anal. 22, 64-75 (2014).

4. Saeed, L. M. et al. Single-walled carbon nanotube and graphene nanodelivery of gambogic acid increases its cytotoxicity in breast and pancreatic cancer cells. J. Appl. Toxicol. 34, 1188-1199 (2014).

5. Wu, J., Yang, R., Zhang, L., Fan, Z. \& Liu, S. Cytotoxicity effect of graphene oxide on human MDA-MB-231 cells. Toxicol. Mech. Methods 25, 312-319 (2015).

6. Perini, G., Palmieri, V., Ciasca, G., De Spirito, M. \& Papi, M. Unravelling the potential of graphene quantum dots in biomedicine and neuroscience. Int. J. Mol. Sci. 21, 3712 (2020).

7. Gurunathan, S., Han, J. W., Eppakayala, V. \& Kim, J. H. Green synthesis of graphene and its cytotoxic effects in human breast cancer cells. Int. J. Nanomed. 8, 1015-1027 (2013).

8. Zhang, B., Wei, P., Zhou, Z. \& Wei, T. Interactions of graphene with mammalian cells: Molecular mechanisms and biomedical insights. Adv. Drug Deliv. Rev. 105, 145-162 (2016).

9. Mazlan, N. S. et al. Interdigitated electrodes as impedance and capacitance biosensors: A review. AIP Conf. Proc. 1885, 020276 (2017).

10. Wang, K., He, M. Q., Zhai, F. H., He, R. H. \& Yu, Y. L. A novel electrochemical biosensor based on polyadenine modified aptamer for label-free and ultrasensitive detection of human breast cancer cells. Talanta 166, 87-92 (2017).

11. Das, R. D., Mondal, N., Das, S. \& Roychaudhuri, C. Optimized electrode geometry for an improved impedance based macroporous silicon bacteria detector. IEEE Sens. J. 12, 1868-1877 (2012).

12. Mamouni, J. \& Yang, L. Interdigitated microelectrode-based microchip for electrical impedance spectroscopic study of oral cancer cells. Biomed. Microdevices 13, 1075-1088 (2011).

13. Bianco, A. Graphene: Safe or toxic? The two faces of the medal. Angew. Chemie Int. Ed. 52, 4986-4997 (2013).

14. Muda, M. R. et al. Fundamental study of reduction graphene oxide by sodium borohydride for gas sensor application. In AIP Conference Proceedings vol. 1808020034 (American Institute of Physics Inc., 2017).

15. Tan, L. L., Ong, W. J., Chai, S. P. \& Mohamed, A. R. Reduced graphene oxide-TiO ${ }_{2}$ nanocomposite as a promising visible-lightactive photocatalyst for the conversion of carbon dioxide. Nanoscale Res. Lett. 8, 1-9 (2013).

16. Johra, F. T., Lee, J. W. \& Jung, W. G. Facile and safe graphene preparation on solution based platform. J. Ind. Eng. Chem. 20, 2883-2887 (2014).

17. Loryuenyong, V., Totepvimarn, K., Eimburanapravat, P., Boonchompoo, W. \& Buasri, A. Preparation and characterization of reduced graphene oxide sheets via water-based exfoliation and reduction methods. Adv. Mater. Sci. Eng. 2013, 1-5 (2013).

18. Muda, M. R., Hanim, K. N., Mat Isa, S. S., Ramli, M. M. \& Jamlos, M. F. High throughput graphene oxide in modified hummers method and annealing effect on different deposition method. Appl. Mech. Mater. 815, 141-147 (2015).

19. Farivar, F. et al. Unlocking thermogravimetric analysis (TGA) in the fight against "Fake graphene" materials. Carbon N. Y. 179, 505-513 (2021).

20. Wang, X., Bai, H. \& Shi, G. Size fractionation of graphene oxide sheets by pH-assisted selective sedimentation. J. Am. Chem. Soc. 133, 6338-6342 (2011). 
21. Shih, C. J., Lin, S., Sharma, R., Strano, M. S. \& Blankschtein, D. Understanding the pH-dependent behavior of graphene oxide aqueous solutions: A comparative experimental and molecular dynamics simulation study. Langmuir 28, 235-241 (2012).

22. Hao, G., Xu, P. Z. \& Li, L. Manipulating extracellular tumour pH: An effective target for cancer therapy. RSC Adv. 8, 22182-22192 (2018).

23. Bernard, S. Why do cells cycle with a 24 hour period?. Genome Inform. 17, 72-79 (2006).

24. Fiorillo, M. et al. Graphene oxide selectively targets cancer stem cells, across multiple tumor types: Implications for non-toxic cancer treatment, via "differentiation-based nano-therapy". Oncotarget 6, 3553 (2015).

25. Chang, Y. et al. In vitro toxicity evaluation of graphene oxide on A549 cells. Toxicol. Lett. 200, 201-210 (2011).

26. Kheiltash, F., Parivar, K., Roodbari, N. H., Sadeghi, B. \& Badiei, A. Effects of 8-hydroxyquinoline-coated graphene oxide on cell death and apoptosis in MCF-7 and MCF-10 breast cell lines. Iran. J. Basic Med. Sci. 23, 871 (2020).

27. Perini, G. et al. International journal of biological macromolecules dynamic structural determinants underlie the neurotoxicity of the N-terminal tau 26-44 peptide in Alzheimer's disease and other human tauopathies. Int. J. Biol. Macromol. 141, 278-289 (2019).

28. Seidel, D. et al. Impedimetric real-time monitoring of neural pluripotent stem cell differentiation process on microelectrode arrays. Biosens. Bioelectron. 86, 277-286 (2016).

29. Ma, H. et al. An impedance-based integrated biosensor for suspended DNA characterization. Sci. Rep. 3, 1-7 (2013).

30. Pandya, H. J. et al. Towards an automated MEMS-based characterization of benign and cancerous breast tissue using bioimpedance measurements. Sens. Actuators B Chem. 199, 259-268 (2014).

31. Kang, G., Yoo, S. K., Kim, H. I. \& Lee, J. H. Differentiation between normal and cancerous cells at the single cell level using 3-D electrode electrical impedance spectroscopy. IEEE Sens. J. 12, 1084-1089 (2012).

32. Abdolahad, M. et al. Single-cell resolution diagnosis of cancer cells by carbon nanotube electrical spectroscopy. Nanoscale 5, 3421-3427 (2013).

33. Sperelakis, N. Cell Physiology Sourcebook: essentials of membrane biophysics, fourth edition. (Elsevier Inc., 2012).

34. Pa, J. \& Pk, K. Biophysical properties of lipids and dynamic membranes. Trends Cell Biol. 16, 538-546 (2006).

35. Anh-Nguyen, T., Tiberius, B., Pliquett, U. \& Urban, G. A. An impedance biosensor for monitoring cancer cell attachment, spreading and drug-induced apoptosis. Sens. Actuators A Phys. 241, 231-237 (2016).

\section{Acknowledgements}

The authors would like to acknowledge the support from the Fundamental Research Grant (FRGS) under a Grant number of FRGS/1/2017/STG04/UNIMAP/02/1 given by the Ministry of Higher Education, Malaysia.

\section{Author contributions}

A.R., M.M.R., N.M., M.A. and D.C.H. wrote the synthesis and characterization of GO. R.M. wrote on cell culture and cell viability. N.O. and A.R. wrote on electrical characterization and responses.

\section{Competing interests}

The authors declare no competing interests.

\section{Additional information}

Correspondence and requests for materials should be addressed to N.H.O.

Reprints and permissions information is available at www.nature.com/reprints.

Publisher's note Springer Nature remains neutral with regard to jurisdictional claims in published maps and institutional affiliations.

(c) (1) Open Access This article is licensed under a Creative Commons Attribution 4.0 International License, which permits use, sharing, adaptation, distribution and reproduction in any medium or format, as long as you give appropriate credit to the original author(s) and the source, provide a link to the Creative Commons licence, and indicate if changes were made. The images or other third party material in this article are included in the article's Creative Commons licence, unless indicated otherwise in a credit line to the material. If material is not included in the article's Creative Commons licence and your intended use is not permitted by statutory regulation or exceeds the permitted use, you will need to obtain permission directly from the copyright holder. To view a copy of this licence, visit http://creativecommons.org/licenses/by/4.0/.

(C) The Author(s) 2021 